\title{
Fluorimetric Method for the Determination of Erythromycin using a Photochemical Derivatization Approach
}

\author{
Virginia de L. M. Finete, ${ }^{a, b}$ Márcia Arissawa ${ }^{c}$ and Ricardo Q. Aucélio*,a
}

${ }^{a}$ Departamento de Química, Pontifícia Universidade Católica do Rio de Janeiro, 22451-900 Rio de Janeiro-RJ, Brazil

${ }^{b}$ Escola Politécnica de Saúde Joaquim Venâncio/Fundação Oswaldo Cruz, 21040-900 Rio de Janeiro-RJ, Brazil

${ }^{c}$ Desenvolvimento Tecnológico, Bio-Manguinhos/Fundação Oswaldo Cruz, 21040-900 Rio de Janeiro-RJ, Brazil

A derivação fotoquímica é proposta como abordagem para induzir fluorescência intensa $(412 / 465 \mathrm{~nm})$ da eritromicina. Parâmetros experimentais importantes como o tempo de irradiação com UV e tipo e concentração de ácido usado para tratar a solução de analito foram ajustadas. Limites de detecção e quantificação de 0,025 e $0,085 \mu \mathrm{g} \mathrm{mL}^{-1}$ foram obtidos com resposta linear até $200 \mu \mathrm{g} \mathrm{mL} \mathrm{m}^{-1}$. O procedimento é seletivo em relação a antibióticos aminoglicosídicos (canamicina, gentamicina e amicacina). O método foi testado em formulações farmacêuticas e em uma vacina contendo eritromicina como conservante, com recuperações do analito entre 98 e $105 \%$.

Photochemical derivatization was proposed to enable intense fluorescence $(412 / 465 \mathrm{~nm})$ from erythromycin. Crucial experimental parameters such as type and concentration of the acid used to treat analyte solutions and UV irradiation time were adjusted. Limits of detection and quantification of 0.025 and $0.085 \mu \mathrm{g} \mathrm{mL}^{-1}$ were achieved with linear range up to $200 \mu \mathrm{g} \mathrm{mL}^{-1}$. The procedure was selective towards the presence of aminoglycoside antibiotics (kanamycin, gentamycin and amikacin). The method was tested using pharmaceutical formulations and one vaccine composition containing erythromycin as a preservative component, with analyte recoveries between 98 and 105\%.

Keywords: photochemical induced fluorescence, erythromycin, pharmaceutical formulations

\section{Introduction}

Erythromycin is the most employed macrolide antibiotic for treating a myriad of infections caused by gram-positive bacteria. ${ }^{1}$ Erythromycin (erythromycin A) has a lactone ring in its chemical structure (Figure 1) and it is often prescribed as an alternative for patients allergic to penicillins. Other close related 14-membered lactone macrolide antibiotics (erythromycin B to F) differ from erythromycin A by small variations in the groups attached in the lactone ring. ${ }^{2}$ Erythromycin has bacteriostatic activity (at concentrations varying from 0.01 to $3 \mu \mathrm{g} \mathrm{mL}^{-1}$ ), inhibiting the synthesis of proteins that are essential for the growing of microorganisms. ${ }^{1,3}$ It has been also employed as part of therapeutic cocktails together with aminoglycoside antibiotics that covers gram-negative microorganisms. For instance, such kind of association (erythromycin and kanamycin) is found in the yellow fever vaccine preserving

*e-mail: aucelior@rdc.puc-rio.br solutions, allowing preservation during production, storage time and use, since each vaccine flask may be employed for multiple doses. ${ }^{4}$

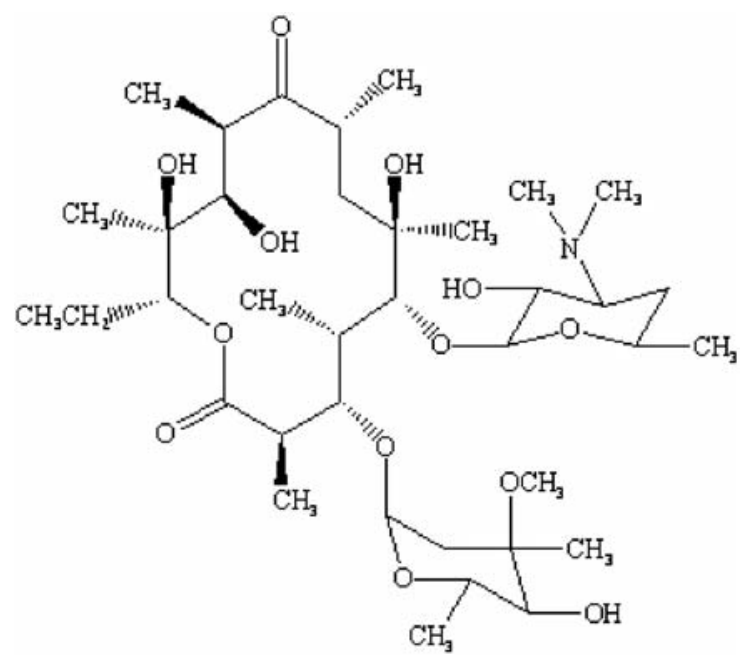

Figure 1. Erythromycin A structure. 
Effective methods to detect and quantify erythromycin in mixtures of antibiotics are based on high-performance liquid chromatography (HPLC), Thin-layer chromatography (TLC) or capillary electrophoresis (CE) ${ }^{5-10}$ A review from Kanfer $e t a l{ }^{2}$ summarizes TLC, HPLC and CE methods for 11 macrolide antibiotics including erythromycin. However, selective methods without employing separation of components are desirable from the point of view of simplicity and cost, especially considering the analysis of less complex matrices. Luminescence based methods are interesting choices from the point of view of selectivity. The literature indicates chemical derivatization procedures to induce fluorescence from erythromycin using the formation of ion pair with erythrosine $\mathrm{B},{ }^{11}$ with the reaction with 9-fluorenylmethylchloroformate ${ }^{12}$ or 9-fluorenylmethyloxycarbonyl chloride. ${ }^{13}$ Erythromycin has also been determined by chemiluminescence using reactions with tris(bipyridine)ruthenium(III), ${ }^{14}$ tris(2-2 'bipyridyl)ruthenium(II), ${ }^{15}$ or using an oxidant/ acid mixture such as $\mathrm{Ce}(\mathrm{IV}) / \mathrm{HClO}_{4}$ or $\mathrm{KMnO}_{4} /$ polyphosphoric acid. ${ }^{16}$ Most of these methods are based on the use of dangerous, expensive and/or toxic reagents. Photochemically induced fluorescence is a very simple and affordable approach since it utilizes UV light instead of chemical reagents to produce fluorescent derivatives from the analyte of interest. In addition, problems related to contamination and high background signal due to the introduction of these derivatization reagents are minimized. ${ }^{17}$

In this paper, a fluorimetric method for the quantification of erythromycin was developed taking advantage of its highly fluorescent photochemical derivative. The method was selective towards the presence of aminoglycoside antibiotics and therefore could be applied in mixtures of these antibiotics. The method was applied successfully to pharmaceutical formulations and in a viral suspension of yellow fever vaccine.

\section{Experimental}

\section{Apparatus}

Fluorescence measurements were made on a PerkinElmer LS-55 luminescence spectrometer using a $10 \mathrm{~nm}$ spectral bandpass, $800 \mathrm{~nm} \mathrm{m^{-1 }}$ scan rate and quartz cuvettes ( $1 \mathrm{~cm}$ optical pathlength). The laboratory made UV reactor described elsewhere ${ }^{17,18}$ was used to enable photoderivatization of samples and standards placed in quartz test tubes $(1.5 \mathrm{~cm}$ i.d. and $15 \mathrm{~cm}$ height). A temperature controlled heating bath (Nova Ética, Brazil) was used for the heating of samples.

\section{Reagents, solutions and samples}

All chemical reagents were of analytical grade. The water (resistivity of $18.2 \mathrm{M} \Omega \mathrm{cm}$ ) was from a Mili-Q system (Bedford, MA, USA). Erythromycin A, erythromycin estolate, kanamycin, gentamycin and amikacin were from Sigma-Aldrich (MO USA). Sulfuric acid ( $\mathrm{d}=1.82 \mathrm{~g} \mathrm{~mL}^{-1}$ and $98 \%$ of $\mathrm{H}_{2} \mathrm{SO}_{4}$ in weight), sucrose and sodium glutamate were obtained from Merck (Darmstadt, Germany). Gelatin (Gelita, IL, USA) and sorbitol (Roquete, Lestrem, France) were also used. Pharmaceutical formulations employed to test the method were Eritromed ${ }^{\circledR}$ (500 mg of erythromycin per tablet) from Medquímica, Brazil and Eritrex ${ }^{\circledR}$ (topic solution $20 \mathrm{mg} \mathrm{mL}^{-1}$ of erythromycin) from Aché, Brazil. A viral suspension of yellow fever vaccine was supplied by BioManguinhos/FIOCRUZ. Erythromycin and kanamycin were added to the viral suspension that originally contains stabilizers as unique excipients.

\section{Procedures}

Erythromycin photochemical derivatization consisted on mixing $4 \mathrm{~mL}$ of erythromycin solution with $3.5 \mathrm{~mL}$ concentrated sulfuric acid followed by a final volume adjustment to $10 \mathrm{~mL}$ with ultrapure water (final concentration of $\mathrm{H}_{2} \mathrm{SO}_{4}$ around $6.3 \mathrm{~mol} \mathrm{~L}^{-1}$ ). Aliquots ( $3 \mathrm{~mL}$ ) of the acidified solution were transferred to quartz tubes that were closed and immersed for 5 min in water at $65{ }^{\circ} \mathrm{C}$. The tubes were then exposed to UV radiation (60 min). Blank solutions were submitted to the same procedure.

Stock solutions of erythromycin were prepared in water. Standard solutions were prepared by sequential dilution of stock solutions with water. For the analysis of commercial tablets, five units were pulverized. A sample mass aliquot was placed in water and submitted to ultra-sonic agitation for $10 \mathrm{~min}$. The solution was then filtered and aliquots of the solution were submitted to the derivatization procedure. Aliquots of $50 \mu \mathrm{L}$ of the solution of topical use were directly dissolved in water and submitted to the photochemically induced fluorescence procedure. The viral suspension (containing $10 \mathrm{mg} \mathrm{mL}^{-1}$ of erythromycin) was directly diluted with water and submitted to the derivatization procedure. In all cases, the final concentration of analyte in the sample solution measured was around $100 \mu \mathrm{g} \mathrm{mL}^{-1}$.

\section{Results and Discussion}

Sulfuric acid or perchloric acid has been used as reagents for some spectrophotometric and spectrofluorimetric 
methods, ${ }^{17,19}$ helping to create chromophores and to promote the breaking of large molecules into small ones with higher fluorescent quantum yield. For erythromycin, sulfuric acid has been proposed as a reactant to enable its spectrophotometric determination. Sugar moieties from the macrolide antibiotics have been indicated as reactive sites with this strong acid that dehydrate sugars forming double bonds that make its derivative absorbing at around $470 \mathrm{~nm} .{ }^{20}$ Amynoglycoside antibiotics also have moieties that may react, forming products with similar absorbing characteristics. Therefore the presence of amynoglycoside antibiotics imposes interferences for the determination of macrolide antibiotics. Perchloric acid was employed to develop an analytical method based on the characteristic fluorescence of $\mathrm{Ce}$ (III) formed from the oxidation of $\mathrm{Ce}$ (IV) in the presence of macrolide antibiotics. ${ }^{16}$ Such procedure is also not selective towards amynoglycoside antibiotics since the same cerium reduction is observed in the presence, for instance, of kanamycin.

\section{Preliminary studies and photochemical amplification of erythromycin fluorescence}

Initial studies have shown that weak fluorescence from erythromycin could be obtained from solutions treated with sulfuric acid. In this case, two fluorescence peaks (450 and $505 \mathrm{~nm}$ ) are observed using the excitation maximum at $412 \mathrm{~nm}$. Such fluorescence was dependent on the acid concentration, and heating of the solution (temperature and heating time). It was also observed that phosphoric acid, nitric acid and hydrochloric acid did not induce relevant fluorescence from erythromycin as it was observed with sulfuric acid. Cachet et al. ${ }^{21}$ indicates few derivatives from the acidic degradation of erythromycin, including formation of double bounds in the lactone ring.

UV irradiation of erythromycin solutions prepared in sulfuric acid have led to a significant amplification of signal with a modification on the fluorescence emission band from two to only one peak (Figure 2). Such modification indicated that a photoderivative with a higher fluorescence quantum yield was obtained. As the irradiation time approached $30 \mathrm{~min}$, signal increase was achieved and the original two emission peaks, characteristic of the nonirradiated solution, were still observed. As the irradiation time was increased to $60 \mathrm{~min}$, maximum fluorescence was obtained with the spectra profile showing a single emission band $(465 \mathrm{~nm})$. For higher irradiation times, the signal intensity decreased, however, keeping the single emission peak profile.

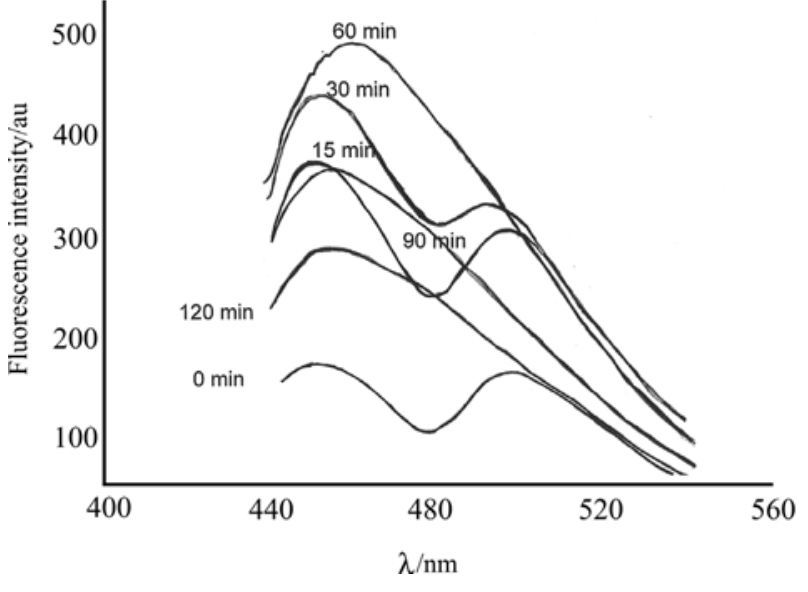

Figure 2. Fluorescence emission spectra from erythromycin as a function of the UV irradiation time (min). Erythromycin $\left(75 \mu \mathrm{g} \mathrm{mL}^{-1}\right)$ in sulfuric acid $6.3 \mathrm{~mol} \mathrm{~L}{ }^{-1}$ heated at $65{ }^{\circ} \mathrm{C}$ for $10 \mathrm{~min}$.

Optimization of the concentration of the sulfuric acid, heating time and temperature

The fluorescence of erythromycin observed in the presence of sulfuric acid was found to be very sensitive to the concentration of the acid, heating time and temperature. In order to evaluate the influence of the final concentration of sulfuric acid, the amount of concentrated sulfuric acid in the solution was varied from 0 to $70 \% \mathrm{v} / \mathrm{v}$. It was observed that maximum signal was achieved by using $35 \% \mathrm{v} / \mathrm{v}$ of the acid $\left(\mathrm{H}_{2} \mathrm{SO}_{4}\right.$ final concentration of $\left.6.3 \mathrm{~mol} \mathrm{~L}^{-1}\right)$ as can be seen in Figure 3A. This behavior was similar to the one observed without UV treatment. However, without UV irradiation, the fluorescence was significantly less intense.

In terms of heating temperature and time, the fluorecence from UV irradiated solutions presented a significantly more robust behavior when compared to the fluorescence from

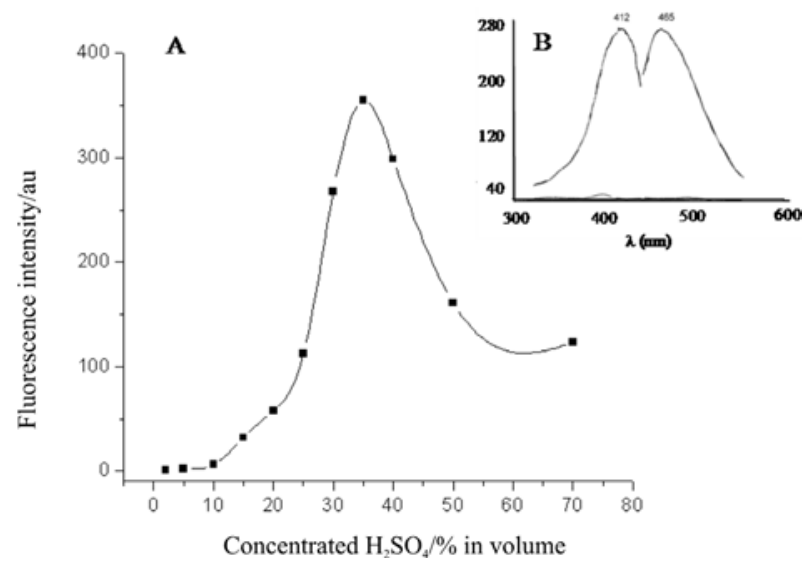

Figure 3. (A) Fluorescence of erythromycin $\left(75 \mu \mathrm{g} \mathrm{mL}^{-1}\right)$ as a function of the volume of concentrated $\mathrm{H}_{2} \mathrm{SO}_{4}$ in the solution. (B) Erythromycin $\left(30 \mu \mathrm{g} \mathrm{mL}^{-1}\right)$ fluorescence excitation and emission spectra after photochemical derivatization $\left(5 \mathrm{~min}\right.$ heating at $65^{\circ} \mathrm{C}$ and $60 \mathrm{~min} \mathrm{UV}$ irradiation. 
non-irradiated solutions. For the irradiated solutions, the maximum fluorescence is obtained for solutions heated during $10 \mathrm{~min}$ at temperatures that could be set from 55 to $85^{\circ} \mathrm{C}$. In contrast, for non-irradiated solutions, fluorescence intensity was duplicated when the heating temperature was increased from 55 to $85{ }^{\circ} \mathrm{C}$. However, even when heating the analyte solutions at $85{ }^{\circ} \mathrm{C}$, fluorescence from non-irradiated solutions were significantly less intense than the UV-irradiated ones. For the irradiated solutions, a $65{ }^{\circ} \mathrm{C}$ heating time was selected. The heating time was also found to be a critical parameter for non-irradiated solutions. By applying a maximum heating time of $20 \mathrm{~min}$ (longer times were avoided because of pressure build up in the sealed vials), fluorescence increased by a factor of two when varied from 5 to $20 \mathrm{~min}$. No fluorescence is observed without heating of the sample. For UV treated solutions, the heating time was found to be a relevant parameter and only two minutes of heating (at $65^{\circ} \mathrm{C}$ ) was enough to induce maximum signal. A 5 min heating time was selected for the procedure. It is interesting to observe that irradiated solutions that were not previously heated presented intense fluorescence, indicating that UV alone is promoting the derivatization of erythromycin.

Figure 3B shows the photochemical induced fluorescence excitation $(412 \mathrm{~nm})$ and emission spectra $(465 \mathrm{~nm})$ for erythromycin under the optimized conditions (erythromycin prepared in aqueous solutions with final concentration of $\mathrm{H}_{2} \mathrm{SO}_{4}$ of $6.3 \mathrm{~mol} \mathrm{~L}^{-1}, 5 \mathrm{~min}$ heating time at $65^{\circ} \mathrm{C}$ followed by a 60 min irradiation time). No difference was observed when comparing signals obtained from erythromycin with the ones from erythromycin estolate.

In order to check the stability of the signal from the erythromycin photoderivative, the fluorescence intensities from solutions containing 30, 60 and $80 \mu \mathrm{g} \mathrm{mL} \mathrm{m}^{-1}$ of erythromycin were monitored in time intervals between 10 and $60 \mathrm{~min}$ after UV treatment. It was found that fluorescence was stable within this time interval.

\section{Analytical performance}

Analytical figures of merit were obtained using optimized conditions to induce fluorescence from erythromycin. In such conditions a linear behavior between concentration of erythromycin $\left(\mathrm{g} \mathrm{mL}^{-1}\right)$ and fluorescence (arbitrary units) was observed ( $\left.\mathrm{Y}=7.5 \times 10^{6} \mathrm{X}-85\right)$ up to $200 \mu \mathrm{g} \mathrm{mL} \mathrm{L}^{-1}$ of analyte. Limits of detection $\left(3 \mathrm{~S}_{\mathrm{b}} / \mathrm{m}\right)$ and quantification $\left(10 \mathrm{~S}_{\mathrm{b}} / \mathrm{m}\right)$ of 0.025 and $0.085 \mu \mathrm{g} \mathrm{mL}^{-1}$ were achieved. By contrast, when compared to the fluorescence observed without UV irradiation $(412 / 450 \mathrm{~nm})$, the linear behavior extended over only $60 \mu \mathrm{g} \mathrm{mL}^{-1}$ with limits of detection and quantification of 0.13 and $0.43 \mu \mathrm{g} \mathrm{mL}-1$ (results for non-irradiated solutions where achieved using $6.3 \mathrm{~mol} \mathrm{~L}^{-1}$ final concentration of $\mathrm{H}_{2} \mathrm{SO}_{4}$ and $20 \mathrm{~min}$ of heating at $85^{\circ} \mathrm{C}$ ). Blank signals were also higher for nonirradiated solutions.

Reproducibility studies were made by performing recovery tests from a test solution $(100 \mu \mathrm{g} \mathrm{mL}-1$ of erythromycin). This study was performed using two different luminescence spectrometers (one LS-55 and one LS-45 model from Perkin-Elmer). Two analytical curves were constructed (one from each of the instruments) in the same day followed by the signal measurement from the test solution. This procedure was repeated for three days. The mean analyte recovery considering all results irrespective of the instrument used $(n=6)$ was $99.7 \pm 0.96 \%$.

The derivatization procedure used for erythromycin was also applied for three aminoglycoside antibiotics (kanamycin, gentamycin and amikacin). The procedure did not induce any fluorescence from these substances. In addition, no statistical differences were observed between the fluorescence signal from solutions containing only erythromycin and from solutions containing the erythromycin and kanamycin in concentrations up to 10 times higher. Studies were also performed using gelatin, sodium glutamate, sucrose and sorbitol with similar results, indicating no interferences in the analyte signal. These substances were chosen because they are commonly employed in some vaccine solutions and as concomitant substances in pharmaceutical formulations.

\section{Application of the method}

The proposed method was applied to determine erythromycin in pharmaceutical formulations and in a viral suspension of yellow fever vaccine (see Table 1). Two different pharmaceutical formulations (one tablet and one solution for topical use) were analyzed with recoveries calculated based on three determinations made in different days. The pulverized tablets $\left(\right.$ Eritromed $^{\circledR}$ ) were also mixed with an equivalent amount of kanamycin in order to simulate a combined formulation containing erythromycin and one aminoglycoside antibiotic. Recoveries were between 101 and $105 \%$ using the analytical curve method for calibration. For the viral suspension, samples were diluted 100 times with water in order to achieve final concentration of $100 \mu \mathrm{g} \mathrm{mL}^{-1}$ and to allow the use of the analytical curve for the successful quantification of the analyte (recovery of 98\%).

\section{Conclusions}

A fluorimetric method based on the photochemical derivatization of erythromycin was developed. Intense 
Table 1. Recovery results for erythromycin $(n=3)$

\begin{tabular}{lccc}
\hline Pharmaceutical formulation & Analyte quantity in the original sample & Analyte recovered quantity & Percent of recovery \\
\hline Eritrex & $20 \mathrm{mg} \mathrm{mL}^{-1}$ & $21 \mathrm{mg} \mathrm{mL}^{-1}$ & $105 \%$ \\
Eritromed & $500 \mathrm{mg}$ & $505 \mathrm{mg}$ & $101 \%$ \\
Eritromed/kanamycin & $500 \mathrm{mg}$ & $510 \mathrm{mg}$ & $102.2 \%$ \\
Viral suspension $^{\mathrm{a}}$ & $10 \mathrm{mg} \mathrm{mL}^{-1}$ & $9.8 \mathrm{mg} \mathrm{mL}^{-1}$ & $98 \%$ \\
\hline
\end{tabular}

aFinal erythromycin concentration in the measured sample solution was $100 \mu \mathrm{g} \mathrm{mL}^{-1}$.

fluorescence was induced by treating erythromycin solutions with sulfuric acid followed by the UV irradiation. The procedure allowed the formation of a stable fluorophor that enabled the determination of erythromycin in pharmaceutical formulations and in a viral suspension. The procedure was found to be simple and avoided the expensive use of chemical reagents being more sensitive and enabling a large linear dynamic range. This new method was also very selective towards amynoglycoside antibiotics, since the photochemical procedure did not induced fluorescence from kanamycin, gentamycin and amikacin. The analytical method was successfully tested in commercial pharmaceutical formulations (tablet and topical solution). A viral suspension of the yellow fever vaccine was also tested with satisfactory results achieved after a simple dilution of the sample, which minimized matrix interferences. This procedure has the potential for automation (flow injection analysis) if the irradiation time is decreased (probably by the use of a more powerful UV reactor).

\section{Acknowledgments}

R. Q. Aucélio thanks CNPq-Brazil for research scholarship. FINEP-Brazil and FAPERJ-Brazil supported this research.

\section{References}

1. Chambers, H. F.; Goodman \& Gilman`s The Pharmacological Basis of Therapeutics, McGraw-Hill: New York, 2001.

2. Kanfer, I.; Skiner M. F.; Walker, R. B.; J. Chromatogr. A 1998, $812,255$.

3. Brisson-Noel, A.; Trieu-Cout, P.; Courvalis, P.; J. Antimicrob. Chemoth. 1988, 22, 13.
4. WHO Requirements for Yellow Fever Vaccine; WHO Technical Report Series 1995, 872.

5. Leal. C.; Codony, R.; Compano, R.; Granados, M.; Prat, M. D., P.; J. Chromatogr. A 2001, 910, 285.

6. Wardrop, J.; Ficker, D.; Franklin, S.; Gorski, R. J.; J. Pharm. Sci. 2000, 89, 1097.

7. Liawruangrath, B.; Liawruangrath, S.; Chromatographia 2001, $54,405$.

8. Garcia-Mayor, M. A.; Garcinuno, R. M.; Fernandez-Hernando, P.; Durand-Alegria, J. S.; J. Chromatogr. A 2006, 1122, 76.

9. Lallo, A. K.; Kanfer, I.; J. Chromatogr. B 1997, 704, 343.

10. Wang, J.; Leung, D.; Lenz, S. P.; J. Agric. Food. Chem. 2006, 54, 2873.

11. Sanz, A.; Tomas, V.; Martinez-Lozano, C.; Prez-Ruiz, T.; Analyst 1993, 118, 567.

12. Zierfels, G.; Petz, M.; Z. Lebensm. Unters F. 1994, 198, 307.

13. Torano, J. S., Guchelaar, H. J.; J. Chromatogr. B 1998, 720, 89.

14. Danielson, N. D.; He, L.; Nofsinger, J. B.; Trelli, L.; J. Pharm. Biomed. Anal. 1989, 7, 1281.

15. Ridlen, J. S.; Skotty, D. R.; Kissinger, P. T.; Nieman, T. A.; J. Chromatog. B 1997, 694, 393.

16. Mitsana-Papazoglou, A.; Fragaki, A.; Chamosfakidi, P.; Calokerinos, A. C.; Anal. Chim. Acta 2000, 410, 153.

17. Coelho, A. L.; Aucélio, R. Q.; Anal. Lett. 2006, 39, 619.

18. Cardoso, C. E.; Martins, R. O. R. Telles, C. A. S.; Aucélio, R. Q.; Microchim. Acta. 2004, 146, 79.

19. Bettaieb, L.; Aaron, J. J.; Turk J. Chem. 2001, 25, 165.

20. Danielson, N. D.; Holeman, J. A.; Kirzner, D. H.; J. Pharm. Biomed. Anal. 1993 11, 121.

21. Cachet, Th.; Van den Mooter, G.; Hauchecorne, R.; Vinckier, C.; Hoogmartens, J.; Int. J. Pharm. 1989, 55, 59.

Received: December 9, 2007 Web Release Date: August 6, 2008 